\title{
REVIEW
}

\section{Therapeutic implications of mesenchymal stem cells in acute lung injury/acute respiratory distress syndrome}

\author{
Yan-Yang Wang ${ }^{1 *}$, Xiu-Zhong Li ${ }^{2}$ and Li-Bing Wang ${ }^{3}$
}

\begin{abstract}
Acute lung injury (ALI), and its more severe form, acute respiratory distress syndrome (ARDS), are syndromes of acute hypoxemic respiratory failure resulting from a variety of direct and indirect injuries to the gas exchange parenchyma of the lungs. Current treatment of ALI/ARDS is primarily supportive, with lung protective ventilation and fluid conserving strategies. Despite improvement in these strategies, recent data indicate that the mortality of ALI/ARDS is still as high as 30 to $50 \%$. Thus, there is a need for innovative therapies to further improve clinical outcomes of ALI/ARDS. Recent studies involving the administration of mesenchymal stem cells (MSCS) for the treatment of experimental ALI/ARDS have shown promising results. This review focuses on existing studies that have tested the use of MSCs in models of ALI/ARDS, and the potential mechanisms underlying their therapeutic effects.
\end{abstract}

\section{Introduction}

Acute lung injury (ALI), and its more severe form, acute respiratory distress syndrome (ARDS), are syndromes of acute hypoxemic respiratory failure resulting from a variety of direct and indirect injuries to the gas exchange parenchyma of the lungs [1,2]. Pulmonary or nonpulmonary infections with sepsis are the most common causes of ALI and ARDS, although gastric aspiration, massive transfusions, trauma and other factors contribute [1,2]. Current treatment of ALI/ARDS is primarily supportive, with lung protective ventilation and fluid conserving strategies [3-5]. Despite improvement in these strategies, recent data indicate that the mortality of ALI/ARDS is still as high as 30 to $50 \%[1,6]$. Thus, there is a need for innovative therapies to further improve clinical outcomes of ALI/ARDS. Although it is a controversial field, some studies have demonstrated that bone marrow-derived mesenchymal stem cells (MSCs) can localize to and/or participate in the development of new lung tissue during the past few years $[7,8]$. In addition, MSC transfer has been attempted as a therapeutic strategy in experimental lung injury. Recent

\footnotetext{
* Correspondence: ydwyy1981@sohu.com

'Department of Radiation Oncology, General Hospital of Ningxia Medical University, No.804 Shengli Str., Yinchuan, Ningxia 750004, China

Full list of author information is available at the end of the article
}

studies involving the administration of MSCs for the treatment of experimental ALI/ARDS have shown promising results [9-11]. This review focuses on existing studies that have tested the use of MSCs in models of ALI/ ARDS, and the potential mechanisms underlying their therapeutic effects.

\section{Mesenchymal stem cells}

MSCs, also named marrow stromal stem cells, were first identified in 1968 by Friedenstein and colleagues [12]. Because there are no MSC-specific cell surface markers, the International Society of Cellular Therapy defined MSCs by the following three criteria in 2006: 1) MSCs must be adherent to plastic under standard tissue culture conditions; 2) MSCs must express certain cell surface markers, such as CD105, CD90 and CD73, but must not express other markers, including CD45, CD34, CD14 or CD11b; and 3) MSCs must have the capacity to differentiate into mesenchymal lineages, including osteoblasts, adipocytes and chrondoblasts, under in vitro conditions [13].

MSCs have now been isolated from a wide variety of tissues, including umbilical cord blood, Wharton's jelly, placenta, adipose and lung tissue [14-18]. Numerous studies have demonstrated that MSCs have a high degree 
of plasticity, as they differentiate into a variety of cell lineages, including fibroblasts, myofibroblasts, osteoblasts, chondroblasts, adipocytes, myoblasts, and epithelial cells $[19,20]$. MSCs do not possess the plasticity of embryonic stem cells, but they offer practical advantages because of their ease of isolation and propagation and also because their use does not involve the ethical issues often raised by the use of embryonic stem cells [21]. Several experimental studies have indicated that MSCs may have potential therapeutic application in clinical disorders, including myocardial infarction, diabetes, hepatic failure, and acute renal failure [22-25]. Experimental studies have also provided evidence indicating that MSCs may be useful for the treatment of ALI/ARDS [26] (Table 1).

\section{Mechanisms of action of mesenchymal stem cells in the treatment of acute lung injury/acute respiratory distress syndrome}

The management of ALI/ARDS with MSCs is suggested to involve two different mechanisms: a cell engraftment mechanism and a paracrine/endocrine mechanism.

\section{Cell engraftment mechanism}

Early studies suggest that engraftment plays an important role in MSC therapy of ALL/ARDS. Krause and colleagues [27] found that a single bone marrow-derived cell could give rise to cells of multiple different organs, including the lung. They reported up to $20 \%$ engraftment of bone marrow-derived cells in the lung, including epithelial cells, from a single hematopoietic precursor. Ortiz and colleagues [28] systemically administered MSCs purified by immunodepletion from male bleomycin-resistant BALB/C mice into female bleomycin-sensitive C57BL/6 recipients. Fluorescence in situ hybridization revealed that engrafted male cells were localized to areas of bleomycin-induced injury and exhibited an epithelium-like morphology. Moreover, purification of type II epithelial cells from the lungs of transplant recipients resulted in a three-fold enrichment of male, donor-derived cells as compared with whole lung tissue. Rojas and colleagues [29] administered bleomycin to mice with or without preceding busulfan-induced myelosuppression. They found that myelosupression increased susceptibility to bleomycin-induced lung injury and that

Table 1 Therapeutics role of MSCs in the pre-clinical models of ALI/ARDS

\begin{tabular}{|c|c|c|c|}
\hline $\begin{array}{l}\text { MSC delivery } \\
\text { route }\end{array}$ & Lung injury model & Mechanism of therapy & Reference \\
\hline \multirow{2}{*}{$\begin{array}{l}\text { IV delivery } \\
\text { immediately post- } \\
\text { injury }\end{array}$} & \multirow[t]{2}{*}{$\begin{array}{l}\text { Murine IT bleomycin-induced } \\
\text { ALI }\end{array}$} & $\begin{array}{l}\text { Engrafted male cells were localized to areas of bleomycin-induced injury and } \\
\text { exhibited an epithelium-like morphology }\end{array}$ & \multirow[t]{2}{*}[28]{} \\
\hline & & $\begin{array}{l}\text { Reduced the degree of bleomycin-induced inflammation and collagen deposition } \\
\text { within lung tissue }\end{array}$ & \\
\hline \multirow[t]{2}{*}{$\begin{array}{l}\text { IV delivery } 6 \text { h post- } \\
\text { injury }\end{array}$} & \multirow[t]{2}{*}{$\begin{array}{l}\text { Murine IT bleomycin-induced } \\
\text { ALI }\end{array}$} & $\begin{array}{l}\text { Differentiation of engrafted BMDMSC into specific and distinct lung cell } \\
\text { phenotypes }\end{array}$ & \multirow[t]{2}{*}[29]{} \\
\hline & & $\begin{array}{l}\text { An increase in circulating levels of G-CSF and GM-CSF and with a decrease in } \\
\text { inflammatory cytokines }\end{array}$ & \\
\hline $\begin{array}{l}\text { IT delivery } 4 \mathrm{~h} \text { and } \\
24 \mathrm{~h} \text { post-injury }\end{array}$ & Murine IT LPS-induced ALI & $\begin{array}{l}\text { Significant decrease in excess lung water, pulmonary edema, bronchoalveolar } \\
\text { lavage protein, endothelial and alveolar epithelial permeability }\end{array}$ & {$[35]$} \\
\hline $\begin{array}{l}\text { IT delivery } 1 \mathrm{~h} \text { and } \\
24 \mathrm{~h} \text { post-injury }\end{array}$ & $\begin{array}{l}\text { Endotoxin-induced ALI in } \\
\text { ex vivo perfused human lung }\end{array}$ & $\begin{array}{l}\text { Secretion of KGF by mesenchymal stem cells resulting in improved endothelial } \\
\text { permeability and restoration of alveolar epithelium fluid transport }\end{array}$ & {$[36]$} \\
\hline \multirow{2}{*}{$\begin{array}{l}\text { IV delivery } \\
\text { immediately post- } \\
\text { injury }\end{array}$} & \multirow{2}{*}{$\begin{array}{l}\text { Murine IT bleomycin-induced } \\
\text { ALI }\end{array}$} & Secretion of IL-1 receptor antagonist & \multirow[t]{2}{*}[37]{} \\
\hline & & Inhibition of TNF-a production by macrophage and IL-1a-dependent T cell line & \\
\hline \multirow{2}{*}{$\begin{array}{l}\text { IV delivery } 1 \mathrm{~h} \text { and } \\
24 \mathrm{~h} \text { post-injury }\end{array}$} & \multirow[t]{2}{*}{ Murine IP LPS-induced ALI } & Prevented endotoxin-induced lung inflammation, injury, and edema & \multirow[t]{2}{*}[39]{} \\
\hline & & $\begin{array}{l}\text { Suppressed the endotoxin-induced increase in circulating pro-inflammatory } \\
\text { cytokines without decreasing circulating levels of anti-inflammatory mediators }\end{array}$ & \\
\hline $\begin{array}{l}\text { IV delivery } \\
\text { immediately post- } \\
\text { injury }\end{array}$ & $\begin{array}{l}\text { Murine IT bleomycin-induced } \\
\text { ALI }\end{array}$ & $\begin{array}{l}\text { Promoted Th1 phenotype and inhibited Th2-mediated allergic airways } \\
\text { inflammation }\end{array}$ & {$[44]$} \\
\hline $\begin{array}{l}\text { IT delivery } 4 \mathrm{~h} \text { post- } \\
\text { injury }\end{array}$ & Murine IT LPS-induced ALI & $\begin{array}{l}\text { Diminished levels of alveolar CD } 4+\text { CD25 }+ \text { Foxp3 }+T_{\text {reg }} \text { and balancing anti- and } \\
\text { pro-inflammatory factors }\end{array}$ & {$[46]$} \\
\hline \multirow{2}{*}{$\begin{array}{l}\text { IV delivery } 6 \mathrm{~h} \text { and } \\
24 \mathrm{~h} \text { post-injury }\end{array}$} & \multirow[t]{2}{*}{ Murine CLP-induced ALI } & Modification of inflammatory gene transcriptional activity & \multirow[t]{2}{*}[48]{} \\
\hline & & $\begin{array}{l}\text { Downregulation of the acute inflammatory response and upregulation of } \\
\text { pathways relevant to phagocytosis and bacterial clearance }\end{array}$ & \\
\hline $\begin{array}{l}\text { IT delivery } 4 \mathrm{~h} \text { and } \\
24 \mathrm{~h} \text { post-injury }\end{array}$ & E. coli pneumonia-induced ALI & $\begin{array}{l}\text { Secretion of the anti-microbial peptide } L L-37 \text { resulting in increased bacterial } \\
\text { clearance }\end{array}$ & {$[49]$} \\
\hline
\end{tabular}

ALI, acute lung injury; ARDS, acute respiratory distress syndrome; BMDMSC, bone marrow-derived mesenchymal stem cell; CLP, cecal ligation and puncture; G-CSF, granulocyte colony-stimulating factor; GM-CSF, granulocyte-macrophage colony-stimulating factor; IP, intraperitoneal; IT, intratracheal; IV, intravenous; KGF, keratinocyte growth factor; LPS, lipopolysaccharide; MSC, mesenchymal stem cell. 
bone marrow-derived MSC transfer was protective. Protection was associated with the differentiation of engrafted MSCs into specific and distinct lung cell phenotypes. However, these results were questioned by multiple groups, who observed only engraftment of leukocyte lineages [30] or observed low engraftment rates in lung injury models of $<1 \%$ [31]. A variety of animal models, method of injury and route of delivery may account for the different results. Lee and colleagues [26] found different mechanisms for two different research models of MSC therapy. In the same study group, the authors suggested the intravenous route might be the preferred approach compared with the intraalveolar route [32]. Results from these studies demonstrate that the role of cell engraftment needs to be researched further [33].

Despite initial interest in their multipotent properties, engraftment in the lung now does not appear to be a key mechanism of action for many MSCs. The beneficial effect of MSCs appears to derive more from their capacity to home to injured tissue beds, interact with injured host cells, and secrete paracrine soluble factors that modulate immune responses as well as alter the responses of endothelium or epithelium to injury through the release of growth factors and antimicrobial peptides [26].

\section{Paracrine/endocrine mechanism}

Much current interest in MSCs has focused on soluble factors due to their ability to secrete multiple paracrine factors such as growth factors, factors regulating endothelial and epithelial permeability, factors regulating innate and adaptive immunity, anti-inflammatory cytokines, and, more recently, antimicrobial peptides that can potentially treat the major abnormalities that underlie ALI/ARDS, including impaired alveolar fluid clearance, altered lung endothelial permeability, dysregulated inflammation, and infection.

A number of groups have reported that MSCs can release several growth factors and regulate endothelial and epithelial permeability, as well as enhance repair. Mei and colleagues [34] delivered syngeneic MSCs with or without transfection with plasmid containing the human ANGPT1 gene (pANGPT1) into mice 30 minutes after intratracheal instillation of lipopolysaccharide (LPS) to induce lung injury. Administration of MSCs significantly reduced LPSinduced pulmonary inflammation. MSCs transfected with pANGPT1 nearly completely reversed the LPS-induced increase in lung permeability.Histological analysis confirmed a marked decrease in inflammatory infiltrates, interalveolar septal thickening, and interstitial edema. Gupta and colleagues [35] tested the effects of bone marrow-derived MSCs in a mouse model of severe lung injury. They administered endotoxin by the intrapulmonary route $(5 \mathrm{mg} / \mathrm{kg})$, which was followed by MSCs 4 hours later (750,000 cells) by the intratracheal route. MSCs reduced the severity of lung injury as measured by excess lung water, wet-to-dry ratio, and bronchoalveolar lavage (BAL) protein concentration. There was also a significant decrease in excess lung water, a measure of pulmonary edema, and BAL protein, a measure of endothelial and alveolar epithelial permeability, in the MSC-treated mice. Lee and colleagues [36] explored the therapeutic capacity of human MSCs to restore alveolar epithelial fluid transport and lung fluid balance from ALI in an ex vivo perfused human lung preparation injured by endotoxin. Treatment with allogeneic human MSCs or its conditioned medium given 1 hour following endotoxininduced lung injury reduced extravascular lung water, improved lung endothelial barrier permeability and restored alveolar fluid clearance. Using small interfering RNA knockdown of potential paracrine soluble factors, secretion of keratinocyte growth factor (KGF) was essential for the beneficial effect of MSCs on alveolar epithelial fluid transport, in part by restoring amiloride-dependent sodium transport. They concluded that treatment with allogeneic human MSCs or the conditioned medium restored normal fluid balance in an ex vivo perfused human lung injured by endotoxin.

Many studies have demonstrated that MSCs also release anti-inflammatory cytokines that can dampen the severity of inflammation in ALL/ARDS. Ortiz and colleagues [28] isolated murine MSCs and administered them intravenously immediately or 7 days following bleomycin-induced lung injury. They found that MSCs improved survival and lung inflammation when administered intravenously. Mice treated with MSCs immediately following bleomycin exposure also had significantly reduced collagen deposition, and reduced expression of matrix metalloproteinases 2 and 9. The degree of the anti-inflammatory effects was striking in comparison to the relatively low levels of lung engraftment. In a subsequent study [37], the same authors found that there was an important contribution by a subpopulation of mouse MSCs that produced interleukin-1 receptor antagonist (IL1RN). IL1RN is a cytokine that competitively competes with IL- $1 \beta$ for IL- 1 receptor binding. IL-1 $\beta$ is one of the major inflammatory cytokines in pulmonary edema fluid in patients with ALI/ARDS [38]. In a model of acute lung injury by intratracheal endotoxin in mice, Gupta and colleagues [35] reported that intratracheal MSCs reduced BAL levels of the pro-inflammatory cytokines TNF- $\alpha$ and macrophage inflammatory protein (MIP)-2 as well as plasma levels of MIP-2. There was a corresponding increase in the anti-inflammatory cytokines IL-10, IL1RN, and IL-13. Xu and colleagues [39] injected C57BL/6 mice intraperitoneally with $1 \mathrm{mg} / \mathrm{kg}$ endotoxin followed by intravenous infusion of MSCs. MSC administration prevented endotoxin-induced lung inflammation, injury, and edema. It also suppressed the endotoxin-induced increase in circulating pro-inflammatory cytokines, including IFN- $\gamma$, IL-1 $\beta$, MIP1- $\alpha$, and KC (murine homolog of IL-8), without 
decreasing circulating levels of anti-inflammatory mediators. Ex vivo co-cultures of MSCs and lung cells from endotoxemic animals demonstrated a bilateral conversation in which lung cells stimulated proliferation and migration of stem cells and suppressed pro-inflammatory cytokine production by lung cells. They concluded that MSCs decrease both the systemic and local inflammatory responses induced by endotoxin. Curley and colleagues [40] determined the potential for MSCs to enhance repair after ventilator-induced lung injury (VILI). MSC therapy enhanced repair following VILI and attenuated alveolar TNF- $\alpha$ concentrations while increasing concentrations of IL-10. The beneficial effect of the MSC secretome on repair of pulmonary epithelial wounds was attenuated by prior depletion of KGF. The authors demonstrated that MSC therapy enhances lung repair following VILI via a paracrine mechanism that may be KGFdependent.

Recently, MSCs have been shown to possess immunomodulatory properties. These include suppression of T-cell proliferation, influencing of dendritic cell maturation and function, suppression of B-cell proliferation and terminal differentiation, and immune modulation of other immune cells such as natural killer cells and macrophages [41-43]. Immunomodulation is another important aspect of the paracrine/endocrine mechanism. Jun and colleagues [44] found that lung MSCs could attenuate the bleomycinassociated pathology and mitigate the development of pulmonary arterial hypertension. Lung MSCs modulated a decrease in numbers of lymphocytes and granulocytes in BAL and demonstrated an inhibition of effector T-cell proliferation in vitro. Goodwin and colleagues [45] ascertained the effects of systemic administration of MSCs in a mouse model of Th2-mediated allergic airways inflammation. Ovalbumin (OVA)-induced allergic airways inflammation was induced in wild-type $\mathrm{C} 57 \mathrm{BL} / 6$ and $\mathrm{BALB} / \mathrm{c}$ mice as well as in IFNy receptor null mice. Both syngeneic and allogeneic MSCs inhibited airways hyper-reactivity and lung inflammation through a mechanism partly dependent on IFN $\gamma$. MSCs promoted Th1 phenotype in vivo as assessed by both OVA-specific CD4 T lymphocyte cytokine production and OVA-specific circulating immunoglobulins. MSCs inhibit Th2-mediated allergic airways inflammation by influencing antigen-specific CD4 T lymphocyte differentiation. Promotion of a Th1 phenotype in antigen-specific CD4 T lymphocytes by MSCs is sufficient to inhibit Th2-mediated allergic airways inflammation through an IFN $\gamma$-dependent process. Sun and colleagues [46] recently reported that transplantation of MSCs ameliorated ALI by enhancing the diminished levels of alveolar CD4 + CD25+ Foxp3 $+\mathrm{T}_{\text {reg }}$ and balancing antiand pro-inflammatory factors in ALI mice. Recent evidence has shown that MSCs can act as an immunostimulatory cell [47]. Their complex function and role in the treatment of ALL/ARDS needs further research.
Recently, some studies found that MSCs have antimicrobial effects through soluble factors. Mei and colleagues [48] evaluated the therapeutic effect of MSCs on a polymicrobial model of sepsis. Sepsis was induced in C57Bl/6J mice by cecal ligation and puncture (CLP), followed 6 hours later by an intravenous injection of MSCs or saline. Twenty-eight hours after CLP, plasma, BAL fluid and tissues were collected for analyses. Bacterial burden was assessed by determining the number of colony forming units (CFUs) in the spleens of saline- or MSC-treated mice. Bacterial CFU counts were high in the spleens of mice that had undergone CLP. Treatment with MSCs significantly reduced CFU counts at 28 hours after CLP, suggesting that MSCs directly or indirectly modulate the ability of the host's phagocytes to clear bacterial infection or participate in bacteria clearance. Although the exact mechanism of increased phagocytosis is not known, the expression microarray analysis performed in this study revealed upregulation of pathways associated with monocyte/macrophage phagocytosis, natural killer cell activity, and antigen presentation.

Krasnodembskaya and colleagues [49] studied the effect of human MSCs derived from bone marrow on the bacterial growth of Gram-negative (Escherichia coli and Pseudomonas aeruginosa) and Gram-positive (Staphylococcus aureus) bacteria. MSCs as well as their conditioned medium demonstrated marked inhibition of bacterial growth in comparison with control medium or normal human lung fibroblasts. Analysis of expression of major antimicrobial peptides indicated that one of the factors responsible for the antimicrobial activity of MSC-conditioned medium against Gram-negative bacteria was the human cathelicidin antimicrobial peptide, hCAP-18/LL-37. Both mRNA and protein expression data showed that the expression of LL-37 in MSCs increased after bacterial challenge. Using an in vivo mouse model of E. coli pneumonia, intratracheal administration of MSCs reduced bacterial growth in the lung homogenates and in the BAL, and administration of MSCs simultaneously with a neutralizing antibody to LL-37 resulted in a decrease in bacterial clearance. In addition, the BAL itself from MSCtreated mice had a greater antimicrobial activity in comparison with the BAL of phosphate-buffered saline-treated mice. Taken together, the results suggest that MSCs exert both direct effects on bacteria and positively modulate the host's phagocytic capacity.

Gupta and colleagues [50] found that treatment with MSCs enhanced bacterial clearance from the alveolar space of the $E$. coli-induced pneumonia mouse model as early as 4 hours after instillation. This reduction in bacterial burden persisted at 24 hours when the number of E. coli in the whole lung homogenate was measured in MSC-treated and control mice. MSCs significantly upregulate their production of lipocalin 2 in response to LPS and inflammatory mediators generated by activated 
macrophages, and this response contributes to the antibacterial effect observed with MSC treatment. In the study of Kim and colleagues [51], ALI was induced by intratracheal $E$. coli instillation, 3 hours after which MSCs, fibroblasts or phosphate-buffered saline were intratracheally administered randomly and survival was analyzed for 7 days post-injury. MSC transplantation increased survival and attenuated lung injuries in ALI mice. MSCs reduced the elevated lung water content at day 3 post-injury and bacterial counts in blood and BAL on day 7 post-injury. Enhancing bacterial clearance is one of the mechanisms of treatment.

\section{Conclusion}

ALI/ARDS is the most common cause of hypoxemic respiratory failure in critically ill patients. Current treatment for ALI/ARDS is supportive and therefore new treatments are needed. MSCs are adult stem cells most commonly isolated from the bone marrow that possess unique immunomodulatory and paracrine properties that make them attractive for cell-based therapy. Although initial research on MSCs was focused on the possibility that cell-based therapy with MSCs could provide a mechanism to replace injured lung epithelium, subsequent studies in the mature and the immature lung have focused more on the paracrine/endocrine properties of MSCs, which have value in limiting lung injury and enhancing lung repair. Given the promising initial results obtained with the use of MSCs in experimental models of ALI/ARDS, there has been enthusiasm to advance cell-based therapy to patients with ALI/ARDS. While clinical trials of MSC-based therapy have been initiated in patients with cardiac, renal and auto-immune diseases, there are several questions that need to be addressed before cell-based therapy can be tested in patients with ALI/ ARDS. Currently, the following four properties are considered the most important: the ability to home to sites of inflammation following tissue injury when injected intravenously; the ability to differentiate into various cell types; the ability to secrete multiple bioactive molecules capable of stimulating recovery of injured cells and inhibiting inflammation; the lack of immunogenicity and the ability to perform immunomodulatory functions [52]. Although clinical trials of MSCs in human subjects, to date, have not reported adverse immune side effects [53,54], future research in this field should continue and focus on elucidating the basic mechanisms responsible for the beneficial effects of MSCs, as well as negatives that are associated with the possible use of MSCs to treat ALL/ARDS patients. In the process, a novel therapy for ALI/ARDS might emerge.

\section{Abbreviations}

ALI: Acute lung injury; ARDS: Acute respiratory distress syndrome; BAL: Bronchoalveolar lavage; CFU: Colony forming unit; CLP: Cecal ligation and puncture; IFN: Interferon; IL: Interleukin; IL1RN: Interleukin-1 receptor antagonist; KGF: Keratinocyte growth factor; LPS: Lipopolysaccharide; MIP: Macrophage inflammatory protein; MSC: Mesenchymal stem cell; OVA: Ovalbumin; TNF: Tumor necrosis factor; VILI: Ventilator-induced lung injury.

\section{Competing interests}

The authors declare that they have no competing interests.

\section{Authors' contributions}

YYW wrote the manuscript. YYW, XZL, and LBW assisted with the revision of English grammar and style. All authors discussed the content and approved the final version of manuscript.

\section{Acknowledgements}

The authors would like to thank Yong-Zhao Zhu, Zhou-Lan Bai and Yu-Hui Zhang for their contributions to this line of research.

\section{Author details}

'Department of Radiation Oncology, General Hospital of Ningxia Medical University, No.804 Shengli Str., Yinchuan, Ningxia 750004, China. ${ }^{2}$ Department of Pulmonary Medicine, General Hospital of Ningxia Medical University, No.804 Shengli Str., Yinchuan, Ningxia 750004, China. ${ }^{3}$ Department of Stem Cell Institution, General Hospital of Ningxia Medical University, No.804 Shengli Str., Yinchuan, Ningxia 750004, China.

\section{Published: 2 May 2013}

\section{References}

1. Rubenfeld GD, Caldwell E, Peabody E, Weaver J, Martin DP, Neff M, Stern EJ, Hudson LD: Incidence and outcomes of acute lung injury. N Engl J Med 2005, 353:1685-1693.

2. Herridge MS, Tansey CM, Matté A, Tomlinson G, Diaz-Granados N, Cooper A, Guest CB, Mazer CD, Mehta S, Stewart TE, Kudlow P, Cook D, Slutsky AS, Cheung AM, Canadian Critical Care Trials Group: Functional disability 5 years after acute respiratory distress syndrome. N Engl J Med 2011, 364:1293-1304.

3. Cepkova M, Matthay MA: Pharmacotherapy of acute lung injury and the acute respiratory distress syndrome. J Intensive Care Med 2006, 21:119-143.

4. The Acute Respiratory Distress Syndrome Network: Ventilation with lower tidal volumes as compared with traditional tidal volumes for acute lung injury and the acute respiratory distress syndrome. N Engl J Med 2000, 342:1301-1308.

5. National Heart, Lung, and Blood Institute Acute Respiratory Distress Syndrome (ARDS) Clinical Trials Network, Wiedemann HP, Wheeler AP, Bernard GR, Thompson BT, Hayden D, de Boisblanc B, Connors AF Jr, Hite $\mathrm{RD}$, Harabin AL: Comparison of two fluid-management strategies in acute lung injury. N Engl J Med 2006, 354:2564-2575.

6. Diaz JV, Brower R, Calfee CS, Matthay MA: Therapeutic strategies for severe acute lung injury. Crit Care Med 2010, 38:1644-1650.

7. Jiang $Y$, Jahagirdar BN, Reinhardt RL, Schwartz RE, Keene CD, Ortiz-Gonzalez XR, Reyes M, Lenvik T, Lund T, Blackstad M, Du J, Aldrich S, Lisberg A, Low WC, Largaespada DA, Verfaillie CM: Pluripotency of mesenchymal stem cells derived from adult marrow. Nature 2002, 418:41-49.

8. Kotton DN, Ma BY, Cardoso WV, Sanderson EA, Summer RS, Williams MC, Fine A: Bone marrow-derived cells as progenitors of lung alveolar epithelium. Development 2001, 128:5181-5188

9. Sueblinvong V, Weiss DJ: Stem cells and cell therapy approaches in lung biology and diseases. Trans/ Res 2010, 156:188-205.

10. Yamada M, Kubo H, Kobayashi S, Ishizawa K, Numasaki M, Ueda S, Suzuki T Sasaki H: Bone marrow-derived progenitor cells are important for lung repair after lipopolysaccharide-induced lung injury. J Immuno/ 2004, 172:1266-1272.

11. Lee JW, Gupta N, Serikov V, Matthay MA: Potential application of mesenchymal stem cells in acute lung injury. Expert Opin Biol Ther 2009, 9:1259-1270. 
12. Friedenstein AJ, Petrakova KV, Kurolesova Al, Frolova GP: Heterotopic of bone marrow. Analysis of precursor cells for osteogenic and hematopoietic tissues. Transplantation 1968, 6:230-247.

13. Dominici M, Le BK, Mueller I, Slaper-Cortenbach I, Marini F, Krause D, Deans R, Keating A, Prockop D, Horwitz E: Minimal criteria for defining multipotent mesenchymal stromal cells. The International Society for Cellular Therapy position statement. Cytotherapy 2006, 8:315-317.

14. Sueblinvong V, Loi R, Eisenhauer PL, Bernstein IM, Suratt BT, Spees JL, Weiss DJ: Derivation of lung epithelium from human cord blood-derived mesenchymal stem cells. Am J Respir Crit Care Med 2008, 177:701-711.

15. Wang HS, Hung SC, Peng ST, Huang CC, Wei HM, Guo YJ, Fu YS, Lai MC, Chen CC: Mesenchymal stem cells in the Wharton's jelly of the human umbilical cord. Stem Cells 2004, 22:1330-1337.

16. Miao Z, Jin J, Chen L, Zhu J, Huang W, Zhao J, Qian H, Zhang X: Isolation of mesenchymal stem cells from human placenta: comparison with human bone marrow mesenchymal stem cells. Cell Biol Int 2006, 30:681-687.

17. Traktuev DO, Merfeld-Clauss S, Li J, Kolonin M, Arap W, Pasqualini R, Johnstone BH, March KL: A population of multipotent CD34-positive adipose stromal cells share pericyte and mesenchymal surface markers, reside in a periendothelial location, and stabilize endothelial networks. Circ Res 2008, 102:77-85.

18. Hoffman AM, Paxson JA, Mazan MR, Davis AM, Tyagi S, Murthy S, Ingenito EP: Lung-derived mesenchymal stromal cell post-transplantation survival, persistence, paracrine expression, and repair of elastase-injured lung. Stem Cells Dev 2011, 20:1779-1792.

19. Prockop DJ, Gregory CA, Spees JL: One strategy for cell and gene therapy: harnessing the power of adult stem cells to repair tissues. Proc Natl Acad Sci U S A 2003, 100:11917-11923.

20. Pittenger MF, Mackay AM, Beck SC, Jaiswal RK, Douglas R, Mosca JD, Moorman MA, Simonetti DW, Craig S, Marshak DR: Multilineage potential of adult human mesenchymal stem cells. Science 1999, 284:143-147.

21. Matthay MA, Thompson BT, Read EJ, McKenna DH Jr, Liu KD, Calfee CS, Lee JW: Therapeutic potential of mesenchymal stem cells for severe acute lung injury. Chest 2010, 138:965-972.

22. Lee RH, Pulin AA, Seo MJ, Kota DJ, Ylostalo J, Larson BL, Semprun-Prieto L, Delafontaine P, Prockop DJ: Intravenous hMSCs improve myocardial infarction in mice because cells embolized in lung are activated to secrete the anti-inflammatory protein TSG-6. Cell Stem Cell 2009, 5:54-63.

23. Lee RH, Seo MJ, Reger RL, Spees JL, Pulin AA, Olson SD, Prockop DJ: Multipotent stromal cells from human marrow home to and promote repair of pancreatic islets and renal glomeruli in diabetic NOD/scid mice. Proc Natl Acad Sci U S A 2006, 103:17438-17443.

24. Parekkadan B, van Poll D, Suganuma K, Carter EA, Berthiaume F, Tilles AW, Yarmush ML: Mesenchymal stem cell-derived molecules reverse fulminant hepatic failure. PLoS One 2007, 2:e941.

25. Tögel F, Hu Z, Weiss K, Isaac J, Lange C, Westenfelder C: Administered mesenchymal stem cells protect against ischemic acute renal failure through differentiation-independent mechanisms. Am J Physiol Renal Physiol 2005, 289:F31-F42.

26. Lee JW, Fang X, Krasnodembskaya A, Howard JP, Matthay MA: Concise review: Mesenchymal stem cells for acute lung injury: role of paracrine soluble factors. Stem Cells 2011, 29:913-919.

27. Krause DS, Theise ND, Collector MI, Henegariu O, Hwang S, Gardner R, Neutzel S, Sharkis SJ: Multi-organ, multi-lineage engraftment by a single bone marrow-derived stem cell. Cell 2001, 105:369-377.

28. Ortiz LA, Gambelli F, McBride C, Gaupp D, Baddoo M, Kaminski N, Phinney DG: Mesenchymal stem cell engraftment in lung is enhanced in response to bleomycin exposure and ameliorates its fibrotic effects. Proc Natl Acad Sci U S A 2003, 100:8407-8411.

29. Rojas M, Xu J, Woods CR, Mora AL, Spears W, Roman J, Brigham KL: Bone marrow-derived mesenchymal stem cells in repair of the injured lung. Am J Respir Cell Mol Biol 2005, 33:145-152.

30. Wagers AJ, Sherwood RI, Christensen JL, Weissman IL: Little evidence for developmental plasticity of adult hematopoietic stem cells. Science 2002 297:2256-2259.

31. Loi R, Beckett T, Goncz KK, Suratt BT, Weiss DJ: Limited restoration of cystic fibrosis lung epithelium in vivo with adult bone marrow-derived cells. Am J Respir Crit Care Med 2006, 173:171-179.

32. Lee JW, Fang X, Song Y, McKenna DH, Read EJ, Matthay MA: Intravenous allogeneic human mesenchymal stem cells home to the site of injury and restore alveolar fluid clearance to a normal level in an ex vivo perfused human lung injured by E.coli endotoxin. Am J Respir Crit Care Med 2010, 181:A3773.

33. Wong AP, Dutly AE, Sacher A, Lee H, Hwang DM, Liu M, Keshavjee S, Hu J, Waddell TK: Targeted cell replacement with bone marrow cells for airway epithelial regeneration. Am J Physiol Lung Cell Mol Physiol 2007, 293:L740-L752.

34. Mei SH, McCarter SD, Deng Y, Parker CH, Liles WC, Stewart DJ: Prevention of LPS-induced acute lung injury in mice by mesenchymal stem cells overexpressing angiopoietin 1. PLOS Med 2007, 4:e269.

35. Gupta N, Su X, Popov B, Lee JW, Serikov V, Matthay MA: Intrapulmonary delivery of bone marrow-derived mesenchymal stem cells improves survival and attenuates endotoxin-induced acute lung injury in mice. J Immunol 2007, 179:1855-1863.

36. Lee JW, Fang X, Gupta N, Serikov V, Matthay MA: Allogeneic human mesenchymal stem cells for treatment of E. coli endotoxin-induced acute lung injury in the ex vivo perfused human lung. Proc Natl Acad SCl U S A 2009, 106:16357-16362.

37. Ortiz LA, Dutreil M, Fattman C, Pandey AC, Torres G, Go K, Phinney DG: Interleukin 1 receptor antagonist mediates the antiinflammatory and antifibrotic effect of mesenchymal stem cells during lung injury. Proc Natl Acad Sci U S A 2007, 104:11002-11007.

38. Geiser T, Atabai K, Jarreau PH, Ware LB, Pugin J, Matthay MA: Pulmonary edema fluid from patients with acute lung injury augments in vitro alveolar epithelial repair by an IL-1 beta-dependent mechanism. Am J Respir Crit Care Med 2001, 163:1384-1388.

39. Xu J, Woods CR, Mora AL, Joodi R, Brigham KL, lyer S, Rojas M: Prevention of endotoxin-induced systemic response by bone marrow-derived mesenchymal stem cells in mice. Am J Physiol Lung Cell Mol Physiol 2007, 293:L131-L141.

40. Curley GF, Hayes M, Ansari B, Shaw G, Ryan A, Barry F, O'Brien T, O'Toole D, Laffey JG: Mesenchymal stem cells enhance recovery and repair following ventilator-induced lung injury in the rat. Thorax 2012, 67:496-501

41. Corcione A, Benvenuto F, Ferretti E, Giunti D, Cappiello V, Cazzanti F, Risso M, Gualandi F, Mancardi GL, Pistoia V, Uccelli A: Human mesenchymal stem cells modulate B-cell functions. Blood 2006, 107:367-372.

42. Yi T, Song SU: Immunomodulatory properties of mesenchymal stem cells and their therapeutic applications. Arch Pharm Res 2012, 35:213-221.

43. Jarvinen L, Badri L, Wettlaufer S, Ohtsuka T, Standiford TJ, Toews GB, Pinsky DJ, Peters-Golden M, Lama VN: Lung resident mesenchymal stem cells isolated from human lung allografts inhibit T cell proliferation via a soluble mediator. J Immunol 2008, 181:4389-4396.

44. Jun D, Garat C, West J, Thorn N, Chow K, Cleaver T, Sullivan T, Torchia EC, Childs C, Shade T, Tadjali M, Lara A, Nozik-Grayck E, Malkoski S, Sorrentino B, Meyrick B, Klemm D, Rojas M: The pathology of bleomycin-induced fibrosis is associated with loss of resident lung mesenchymal stem cells that regulate effector T-cell proliferation. Stem Cells 2011, 29:725-735.

45. Goodwin M, Sueblinvong V, Eisenhauer P, Ziats NP, LeClair L, Poynter ME, Steele $C$, Rincon $M$, Weiss DJ: Bone marrow-derived mesenchymal stromal cells inhibit Th2-mediated allergic airways inflammation in mice. Stem Cells 2011, 29:1137-1148

46. Sun J, Han ZB, Liao W, Yang SG, Yang Z, Yu J, Meng L, Wu R, Han ZC: Intrapulmonary delivery of human umbilical cord mesenchymal stem cells attenuates acute lung injury by expanding CD4 + CD25+ Forkhead Boxp3 (FOXP3) + regulatory T cells and balancing anti- and proinflammatory factors. Cell Physiol Biochem 2011, 27:587-596.

47. Raffaghello L, Bianchi G, Bertolotto M, Montecucco F, Busca A, Dallegri F, Ottonello L, Pistoia V: Human mesenchymal stem cells inhibit neutrophil apoptosis: a model for neutrophil preservation in the bone marrow niche. Stem Cells 2008, 26:151-162.

48. Mei SH, Haitsma JJ, Dos Santos CC, Deng Y, Lai PF, Slutsky AS, Liles WC, Stewart DJ: Mesenchymal stem cells reduce inflammation while enhancing bacterial clearance and improving survival in sepsis. Am J Respir Crit Care Med 2010, 182:1047-1057.

49. Krasnodembskaya A, Song Y, Fang X, Gupta N, Serikov V, Lee JW, Matthay MA: Antibacterial effect of human mesenchymal stem cells is mediated in part from secretion of the antimicrobial peptide LL-37. Stem Cells 2010, 28:2229-2238.

50. Gupta N, Krasnodembskaya A, Kapetanaki M, Mouded M, Tan X, Serikov V, Matthay MA: Mesenchymal stem cells enhance survival and bacterial clearance in murine Escherichia coli pneumonia. Thorax 2012, 67:533-539. 
51. Kim ES, Chang YS, Choi SJ, Kim JK, Yoo HS, Ahn SY, Sung DK, Kim SY, Park YR, Park WS: Intratracheal transplantation of human umbilical cord blood-derived mesenchymal stem cells attenuates Escherichia coliinduced acute lung injury in mice. Respir Res 2011, 12:108.

52. Wang SH, Qu XB, Zhao RC: Clinical applications of mesenchymal stem cells. J Hematol Oncol 2012, 5:19.

53. Yamout B, Hourani R, Salti H, Barada W, El-Hajj T, Al-Kutoubi A, Herlopian A, Baz EK, Mahfouz R, Khalil-Hamdan R, Kreidieh NM, El-Sabban M, Bazarbachi A: Bone marrow mesenchymal stem cell transplantation in patients with multiple sclerosis: a pilot study. J Neuroimmunol 2010, 227:185-189.

54. Perez-Simon JA, Lopez-Villar O, Andreu EJ, Rifon J, Muntion S, Campelo MD, Sanchez-Guijo FM, Martinez C, Valcarcel D, Canizo CD: Mesenchymal stem cells expanded in vitro with human serum for the treatment of acute and chronic graft-versus-host disease: results of a phase I/II clinical trial. Haematologica 2011, 96:1072-1076.

doi:10.1186/scrt193

Cite this article as: Wang et al:: Therapeutic implications of mesenchymal stem cells in acute lung injury/acute respiratory distress syndrome. Stem Cell Research \& Therapy 2013 4:45. 